\title{
Zinc Depletion by TPEN Induces Apoptosis in Human Acute Promyelocytic NB4 Cells
}

\author{
Bo Zhua Jiayu Wanga Feng Zhou ${ }^{a}$ Yingting Liua Yueyang Lai ${ }^{a}$ Jie Wang ${ }^{a}$ \\ Xiao Chen ${ }^{a}$ Dianhua Chen ${ }^{a}$ Lan Luo $^{a}$ Zi-Chun Hua a,b \\ aThe State Key Laboratory of Pharmaceutical Biotechnology, School of Life Sciences, Nanjing University,

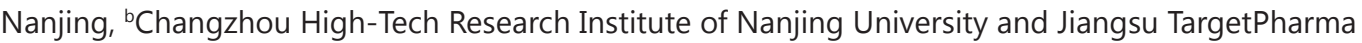 \\ Laboratories Inc., Changzhou, PR China
}

\section{Key Words}

TPEN • Zinc • Nitric oxide $・$ Apoptosis $•$ Acute promyelocytic leukemia

\begin{abstract}
Background/Aims: The effects of zinc signaling on proliferation or apoptosis of leukemia cells remain elusive. In the present study, we used N, N, N', N'-tetrakis-(2-pyridylmethyl)-ethylenediamine (TPEN), a membrane-permeable zinc chelator, to evaluate the effect of zinc depletion on survival and apoptosis of NB4 acute promyelocytic leukemia (APL) cells. Methods: The proapoptotic effects of TPEN on NB4 cells were examined by flow cytometry, and observed using an optical microscope. Intracellular labile zinc, nitric oxide (NO) or reactive oxygen species (ROS) changes caused by TPEN were measured by flow cytometry. We then explored possible roles of the crosstalk between intracellular labile zinc signaling and nitric oxide signaling in TPEN-triggered apoptosis. Results: we found that TPEN induced apoptosis in NB4 APL cells in a dosage-dependent manner. We further demonstrated that TPEN triggered apoptosis by attenuating intracellular zinc and nitric oxide signaling in NB4 cells. Both exogenous zinc supplement and the nitric donor sodium nitroprusside (SNP) pre-incubation reversed TPEN-mediated inhibition of intracellular $\mathrm{NO}$ and $\mathrm{Zn}^{2+}$ signaling, and rescued NB4 cells from apoptosis. Conclusion: These results suggest for the first time that crosstalk between zinc signaling and nitric oxide pathway is essential for the survival of NB4 cells. TPEN induces apoptosis in NB4 cells via negatively regulating intracellular NO and $\mathrm{Zn}^{2+}$ signaling. Our in vitro data suggest that zinc depletion by TPEN may be a potential therapeutic strategy for APL.
\end{abstract}

\section{Introduction}

Acute myeloid leukemia (AML) is a heterogenous group of leukemias that result from malignant transformation of hematopoietic precursors [1,2]. Acute promyelocytic leukemia (APL) is a subtype of acute myeloid leukemia characterized by a t (15:17) translocation that yields a PML/ RAR $\alpha$ fusion oncoprotein, which blocks maturation and apoptosis of neutrophils at the promyelocyte stage $[3,4]$. Due to the tendency for severe bleeding in patients, APL was historically described as the most malignant form of acute leukemia with 


\section{Cellular Physiology Cell Physiol Biochem 2017;42:1822-1836 \\ \begin{tabular}{ll|l} 
and Biochemistry $10.1159 / 000479539$ & $\begin{array}{l}\text { ( ) 2017 The Author(s). Published by S. Karger AG, Basel } \\
\text { www.karger.com/cpb }\end{array}$ \\
\hline
\end{tabular} \\ Zhu et al.: TPEN Induces Apoptosis in NB4 Cells}

a fatal course of only weeks [5]. Introduction of all-trans retinoic acid (ATRA) and arsenic trioxide (ATO) in the treatment has largely improved the clinical outcomes of patients with APL $[6,7]$. However, about $48 \%$ of the APL patients treated with ATRA may develop the ATRA-related differentiation syndrome [8]. Some side effects of ATO treatment exist, and the safety of long-term application of ATO is of great concern [9]. Furthermore, resistance or intolerance to these drugs is often encountered [10]. There are still some APL patients with poor clinical outcomes $[11,12]$. Hence, new chemicals and strategies with therapeutic potential for APL are still of intense interest.

Zinc is vital for numerous cellular processes, including survival, proliferation, aging, apoptosis, autophagy, and differentiation, both in normal and cancer cells [13-16]. As a cofactor for an estimated 3,000 human proteins [17], aberrations in zinc homeostasis contribute to development and progression of human cancers $[18,19]$. Previous studies are mainly focused on the cytotoxicity of excessive zinc supplement on cancer cells [20-22]. Recently, N, N, N', N'-tetrakis-(2-pyridylmethyl)-ethylene-diamine (TPEN), a membranepermeable zinc chelator, shows pro-apoptotic effects on some cancer cells, indicating that zinc depletion may be a potential strategy for cancer treatment [23, 24]. However, zinc homeostasis has mainly been studied in solid tumor cells, accumulating only a limited wealth of zinc-related study in cancer biology. Although low serum levels of zinc have been noted in certain kinds of leukemia, the underlying reasons are rarely studied $[25,26]$. The role of zinc homeostasis in survival or apoptosis in leukemia cells remains unclear.

Nitric oxide (NO) has both pro- and anti-apoptotic effects on cancer cells, mainly depending on its concentration [27-30]. Physiological level of NO signaling is essential for cell survival and proliferation, and depletion of NO inhibits proliferation and induces apoptosis in various cancer cells $[31,32]$. Meanwhile, excessive NO triggers apoptosis of cancer cells with evaluated oxidative stress [33]. It has been reported that NO can promote $\mathrm{Zn}^{2+}$ release from intracellular storage and trigger neuronal cell death [34]. However, effects of the crosstalk between $\mathrm{NO}$ and $\mathrm{Zn}^{2+}$ signaling on cancer cells, especially on leukemia cells, remain to be explored.

In the present study, we investigated the effects of zinc depletion by TPEN on apoptosis of human acute promyelocytic NB4 cells. Pro-apoptotic effect exerted by TPEN on NB4 cells was observed and quantitatively determined by flow cytometry. The crosstalk between labile zinc signaling and nitric oxide signaling was then examined to elucidate its role in TPEN-mediated death of leukemia cells.

\section{Materials and Methods}

\section{Cell culture and reagents}

The NB4, Kasumi-3, THP-1 and U937 acute myeloid leukemia (AML) cell lines were grown in RPMI 1640 medium, supplemented with $10 \%$ heat-inactivated fetal bovine serum (FBS), $100 \mu \mathrm{g} / \mathrm{ml}$ streptomycin, $100 \mathrm{U} / \mathrm{ml}$ penicillin and $2 \mathrm{mM}$ L-glutamine (All from Thermo Fisher Scientific, Waltham, MA, USA), and maintained in a humidified incubator $\left(37^{\circ} \mathrm{C}, 5 \% \mathrm{CO}_{2}\right)$. TPEN, Zinc sulfate $\left(\mathrm{ZnSO}_{4}\right), \mathrm{N}$-acetylcysteine (NAC), Sodium nitroprusside (SNP), Carboxy-PTIO (C-PTIO), Dichloro-dihydro-fluorescein diacetate (DCFH DA) and Propidium iodide (PI) were purchased from Sigma-Aldrich (St. Louis, MO, USA). 4-amino-5-methylamino-2', 7'-difluorofluorescein diacetate (DAF-FM DA) and Zinpyr-1 were purchased from Santa Cruz Biotechnology (Santa Cruz, CA, USA). The pan-caspase inhibitor Z-VAD-FMK and the caspase-8 inhibitor Z-IETD-FMK were purchased from Selleck Chemicals (Houston, TX, USA). The pan-caspase inhibitor Q-VD-OPh was purchased from MedChem Express (Monmouth Junction, NJ, USA). The caspase-8 inhibitor Ac-IETD-CHO was purchased from Santa Cruz Biotechnology (Santa Cruz, CA, USA).

Cell viability analysis

After being stimulated with indicated concentrations of TPEN for $24 \mathrm{~h}$, the viability of NB4 cells was measured using Cell Counting Kit-8 (CCK-8, Beyotime, Nantong, China) according to the manufacturer's instructions. 


\section{Cellular Physiology Cell Physiol Biochem 2017;42:1822-1836 \begin{tabular}{l|l|l} 
and Biochemistry Published online: July 27, 2017 & $\begin{array}{l}\text { @ 2017 The Author(s). Published by S. Karger AG, Basel } \\
\text { www.karger.com/cpb }\end{array}$ \\
\hline
\end{tabular} \\ Zhu et al.: TPEN Induces Apoptosis in NB4 Cells}

Cell cycle assay

After being fixed in $70 \%$ ethanol at $-20^{\circ} \mathrm{C}$ overnight, cells were pelleted, washed with PBS twice, and then resuspended in propidium iodide $(20 \mu \mathrm{g} / \mathrm{ml})$ and RNase $(200 \mu \mathrm{g} / \mathrm{ml})$-containing buffer. Following incubation at $37^{\circ} \mathrm{C}$ for $30 \mathrm{~min}$ in the dark, NB4 cells were analyzed by flow cytometry for cell cycle distribution.

Flow cytometric analysis for apoptosis

Cells were stimulated with TPEN with or without $\mathrm{ZnSO}_{4}$, SNP, or C-PTIO for the indicated time periods. Cells were then harvested, washed with a $\mathrm{Ca}^{2+}$-containing binding buffer $(10 \mathrm{mM}$ HEPES/NaOH, $140 \mathrm{mM}$ $\mathrm{NaCl}$, and $2.5 \mathrm{mM} \mathrm{CaCl}_{2}, \mathrm{pH}=7.4$ ) and then co-stained with Annexin V-EGFP and PI at room temperature for $20 \mathrm{~min}$. PI was added just $5 \mathrm{~min}$ before flow cytometric analysis. Annexin V-positive/PI-negative, and AnnxinV-positive/PI- positive populations represent cells in early and late apoptosis respectively.

Measurement of intracellular reactive oxygen species (ROS) by flow cytometry

Intracellular ROS level was detected by flow cytometry using DCFH DA, according to the manufacturer's instructions.

Measurement of intracellular nitric oxide by flow cytometry

DAF-FM DA is a sensitive and cell-permeable fluorescent probe for the detection of intracellular NO production. About $1 \times 10^{6}$ cells were harvested and loaded with $5 \mu \mathrm{M}$ DAF-FM DA at $37^{\circ} \mathrm{C}$ in the dark for 20 min. Cells were then washed three times with PBS and analyzed by flow cytometry.

Measurement of intracellular labile $\mathrm{Zn}^{2+}$ by flow cytometry

Relative labile $\mathrm{Zn}^{2+}$ level in NB4 cells was measured as previously described [35]. Briefly, about $1 \times 10^{6}$ cells were harvested and loaded with $5 \mu \mathrm{M}$ Zinpyr -1 at $37^{\circ} \mathrm{C}$ in the dark for $20 \mathrm{~min}$, washed three time with PBS, and then analyzed by flow cytometry.

\section{Western blot}

Total Proteins were extracted from NB4 cells with cell lysis buffer for western blotting and immunoprecipitation (Beyotime Institute of Biotechnology, Nantong, China), separated by 10\% SDS-PAGE, and then transferred onto polyvinylidene fluoride (PVDF) membranes. The membranes were blocked for $1 \mathrm{~h}$ at room temperature with 5\% non-fat milk dissolved in TBST buffer, and then incubated with primary antibodies at $4{ }^{\circ} \mathrm{C}$ overnight. Washed with TBST for three times (10 min for each time), the membranes were incubated with secondary antibodies for $1 \mathrm{~h}$ at room temperature. Another round of membrane washes with TBST were performed before chemiluminescent detection. Anti-Caspase 3, anti-cleaved-Caspase 3, anti-Caspase 8, and anti-Caspase 9 antibodies were purchased from Cell Signaling Technology (Danvers, MA, USA). The $\beta$-actin antibody was obtained from Abgent (San Diego, CA, USA).

\section{Statistical analysis}

All analyses were performed using GraphPad Prism software (Version 6.02, La Jolla, CA, USA). The results are expressed as mean values with standard deviations. Student's t-test, or one-way ANOVA test with Dunnett's post-hoc was performed as appropriate. Differences were considered statistically significant when $P<0.05$.

\section{Results}

TPEN triggers apoptosis of NB4 APL cells in a dose- and caspase-dependent manner

We found that TPEN is cytotoxic to NB4 cells in a dose-dependent way using CCK8 screening (Fig. 1A). Exposure to $5 \mu \mathrm{M}$ TPEN for $24 \mathrm{~h}$ was enough to induce an approximate reduction of 50\% in cell viability. And almost $90 \%$ inhibition of NB4 cells was achieved when incubated with $25 \mu \mathrm{M}$ TPEN for $24 \mathrm{~h}$. These data suggest that TPEN induces growth arrest or triggers apoptosis of NB4 APL cells in a dose-dependent manner. We further observed cell morphology of NB4 cells exposed to TPEN under an inverted microscope, and characterized 


\section{Cellular Physiology Cell Physiol Biochem 2017;42:1822-1836 \begin{tabular}{c|c|c|} 
DOI: 10.1159/000479539 & O 2017 The Author(s). Published by S. Karger AG, Basel \\
wwwwkargercom/cpb
\end{tabular} Zhu et al.: TPEN Induces Apoptosis in NB4 Cells}

apoptotic NB4 cells using dual staining of Annexin V and PI. Typical apoptotic morphology of NB4 cells, such as cell shrinkage or cytoplasmic vacuolar changes, was observed following treatment with TPEN for $24 \mathrm{~h}$ at $5 \mu \mathrm{M}$ (Fig. 1B). Annexin V/PI staining assay yielded similar results (Fig. 1C). Treated with $5 \mu \mathrm{M}$ TPEN for $24 \mathrm{~h}$, activation and cleavage of caspase- $3,-8$, and -9 was detected (Fig. 1D). Cell cycle assay results suggest that NB4 cells treated with $5 \mu \mathrm{M}$ TPEN for $12 \mathrm{~h}$ arrested in G0/G1 stage in the initial stages of apoptosis (Fig. 1E). We further pre-treated NB4 cells with pan-caspase inhibitors or caspase-8 inhibitors before

Fig. 1. Zinc chelator TPEN suppresses the viability and induces apoptosis of NB4 APL cells. (A) NB4 cells were treated with indicated concentrations of TPEN (0-25 $\mu \mathrm{M})$ for $24 \mathrm{~h}$, and then subjected to a CCK-8 assay for cell viability analysis. (B) Cell morphology was observed and recorded using an optical microscope. The scale bar represents $20 \mu \mathrm{m}$. A partially enlarged view was shown in the lower left corner of every picture. (C) Apoptosis of NB4 cells treated with indicated concentrations of TPEN (0-25 $\mu \mathrm{M})$ was measured with Annexin V/PI staining by flow cytometry. Early apoptotic cells: Annexin V+/PI-; necrotic/late apoptotic cells: Annexin V+/PI+. (D) Western blot analysis of caspase-8,-9 and -3 expression in NB4 cells treated with TPEN $(5 \mu \mathrm{M})$ for indicated time periods $0-24$ h). $\beta$-Actin served as

A

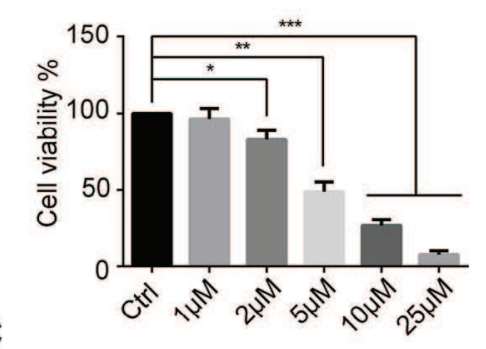

C
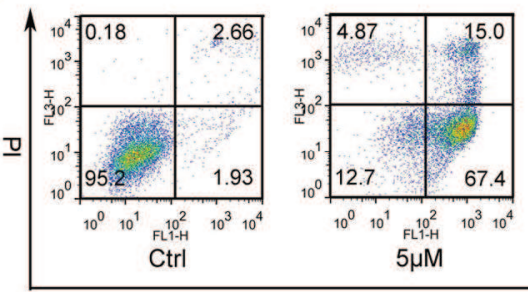

B
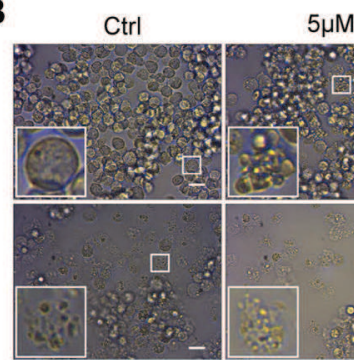

$10 \mu \mathrm{M}$
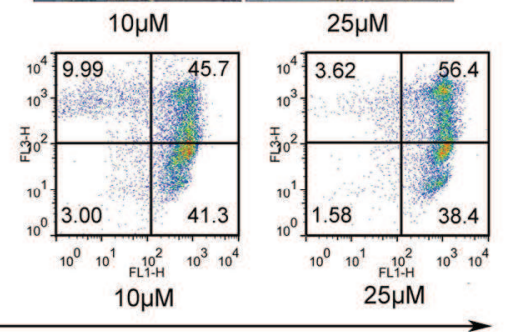

Annexin V

D

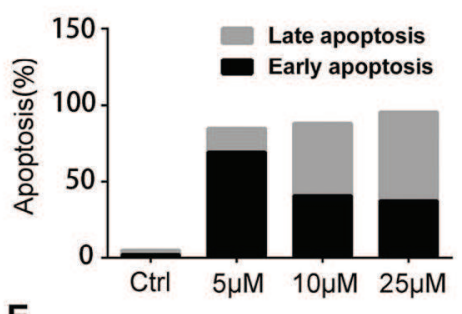

E
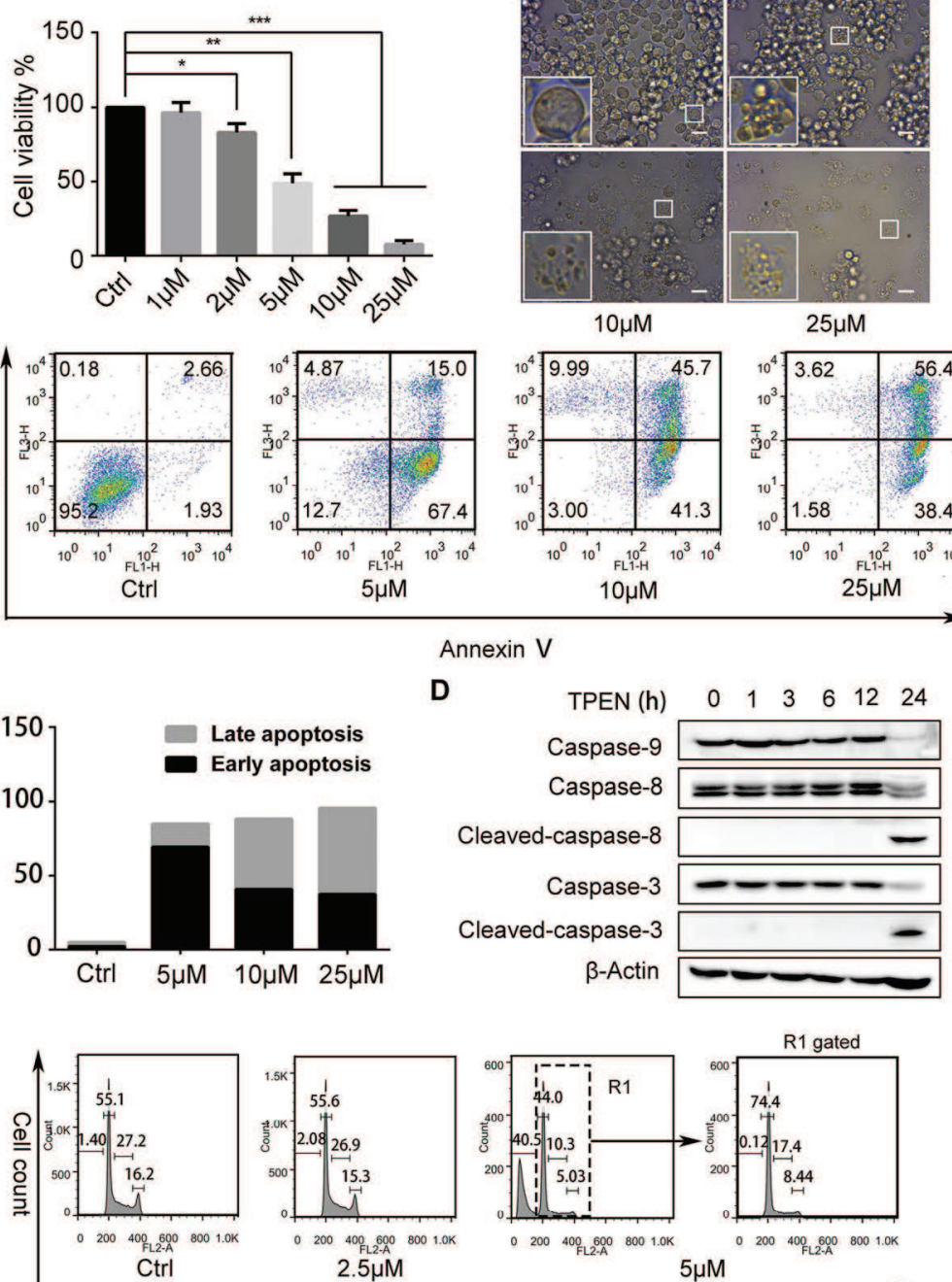

\section{4}

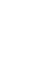

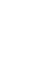




\section{Cellular Physiology \\ Cell Physiol Biochem 2017;42:1822-1836 \\ \begin{tabular}{l|l|l} 
and Biochemistry 10.1159/000479539 & $\begin{array}{l}\text { () } 2017 \text { The Author(s). Published by S. Karger AG, Basel } \\
\text { www.karger.com/cpb }\end{array}$ \\
\hline
\end{tabular}

Fig. 2. The pan-caspase inhibitors block TPEN-induced apoptosis of NB4 cells. NB4 cells were pre-treated with $50 \mu \mathrm{M}$ Z-VAD-FMK or $50 \mu \mathrm{M}$ Q-VD-OPh for $1 \mathrm{~h}$, and then treated with $5 \mu \mathrm{M}$ TPEN for $24 \mathrm{~h}$. (A) Cell morphology was observed and recorded using an optical microscope. The scale bar represents $20 \mu \mathrm{m}$. A partially enlarged view was shown in the lower left corner of every picture. (B) Apoptosis rate was measured with Annexin V/PI dual staining by flow cytometry.
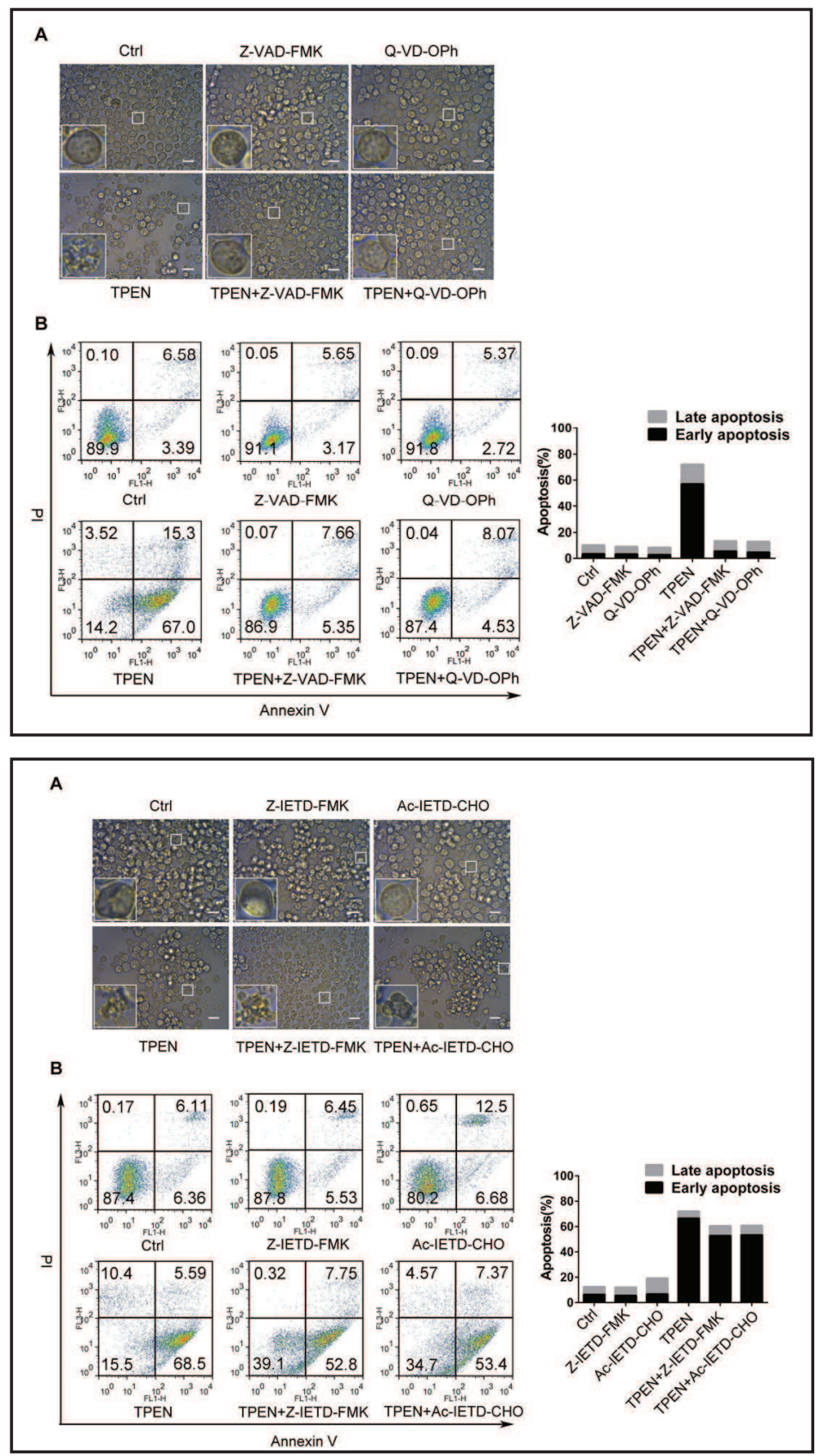

Fig. 3. The caspase- 8 inhibitors do not rescue NB4 cells from TPEN-triggered apoptosis. NB4 cells were pre-treated with $50 \mu \mathrm{M}$ Z-IETD-FMK or $100 \mu \mathrm{M}$ Ac-IETD$\mathrm{CHO}$ for $1 \mathrm{~h}$, and then treated with $5 \mu \mathrm{M}$ TPEN for $24 \mathrm{~h}$. (A) Cell morphology was observed and recorded using an optical microscope. The scale bar represents $20 \mu \mathrm{m}$. A partially enlarged view was shown in the lower left corner of every picture. (B) Apoptosis rate was measured with Annexin V/PI dual staining by flow cytometry.

TPEN stimulation, and found that TPEN-triggered apoptosis was blocked by pan-caspase inhibitors (Fig. 2), not caspase-8 inhibitors (Fig. 3). These data indicated that TPEN mainly induced apoptosis via intrinsic pathway in NB4 APL cells. We also found that TPEN inhibited cell viability and induced apoptosis in another three AML cell lines, including Kasumi-3, THP-1 and U937 (Fig. 4 and Fig. 5).

TPEN induces apoptosis of NB4 cells with decreased intracellular ROS level

Oxidative stress plays important roles in regulating apoptosis of leukemia cells [36, 37]. Previous studies have demonstrated that elevated ROS are involved in TPEN-induced apoptosis of human acute lymphoblastic leukemia (ALL) cells [38]. In contrast, TPENinduced apoptosis in NB4 APL cells associated with decreased intracellular ROS (Fig. 6A), and the widely used ROS scavenger NAC failed to rescue NB4 cells from TPEN-induced apoptosis (Fig. 6B and 6C). 


\section{Cellular Physiology Cell Physiol Biochem 2017;42:1822-1836 \begin{tabular}{ll|l} 
DOI: 10.1159/000479539 & $\begin{array}{l}\text { () } 2017 \text { The Author(s). Published by S. Karger AG, Basel } \\
\text { www }\end{array}$
\end{tabular}

A

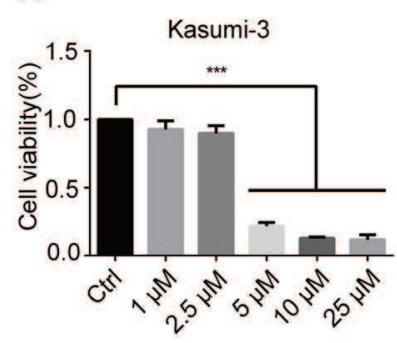

B

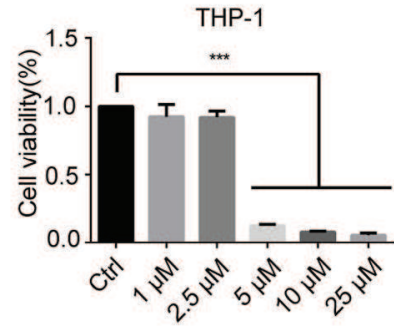

C

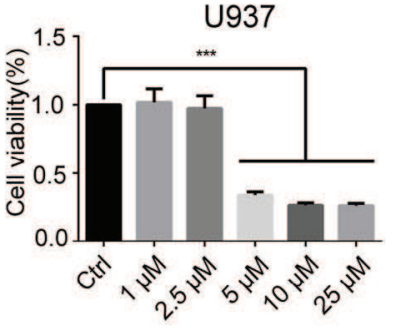

Fig. 4. TPEN inhibits cell viability in Kasumi-3, THP-1 and U937 AML cells. Kasumi-3 (A), THP-1 (B) or U937 (C) cells were treated with indicated concentrations of TPEN (0-25 $\mu \mathrm{M})$ for $24 \mathrm{~h}$, and then subjected to a CCK-8 assay for cell viability analysis. All experiments were done at least in three independent replicates and data were shown as mean \pm SD. ${ }^{* * *} P<0.005$.

Fig. 5. TPEN induces apoptosis in Kasumi-3, THP-1 and U937 AML cells. Kasumi-3, THP-1, and U937 cells were treated with indicated concentrations of TPEN (0$25 \mu \mathrm{M}$ ) for $24 \mathrm{~h}$. (A) Cell morphology was observed and recorded using an optical microscope. The scale bar represents $20 \mu \mathrm{m}$. A partially enlarged view was shown in the lower left corner of every picture. (B) Apoptosis rate was measured with Annexin V/PI dual staining by flow cytometry.

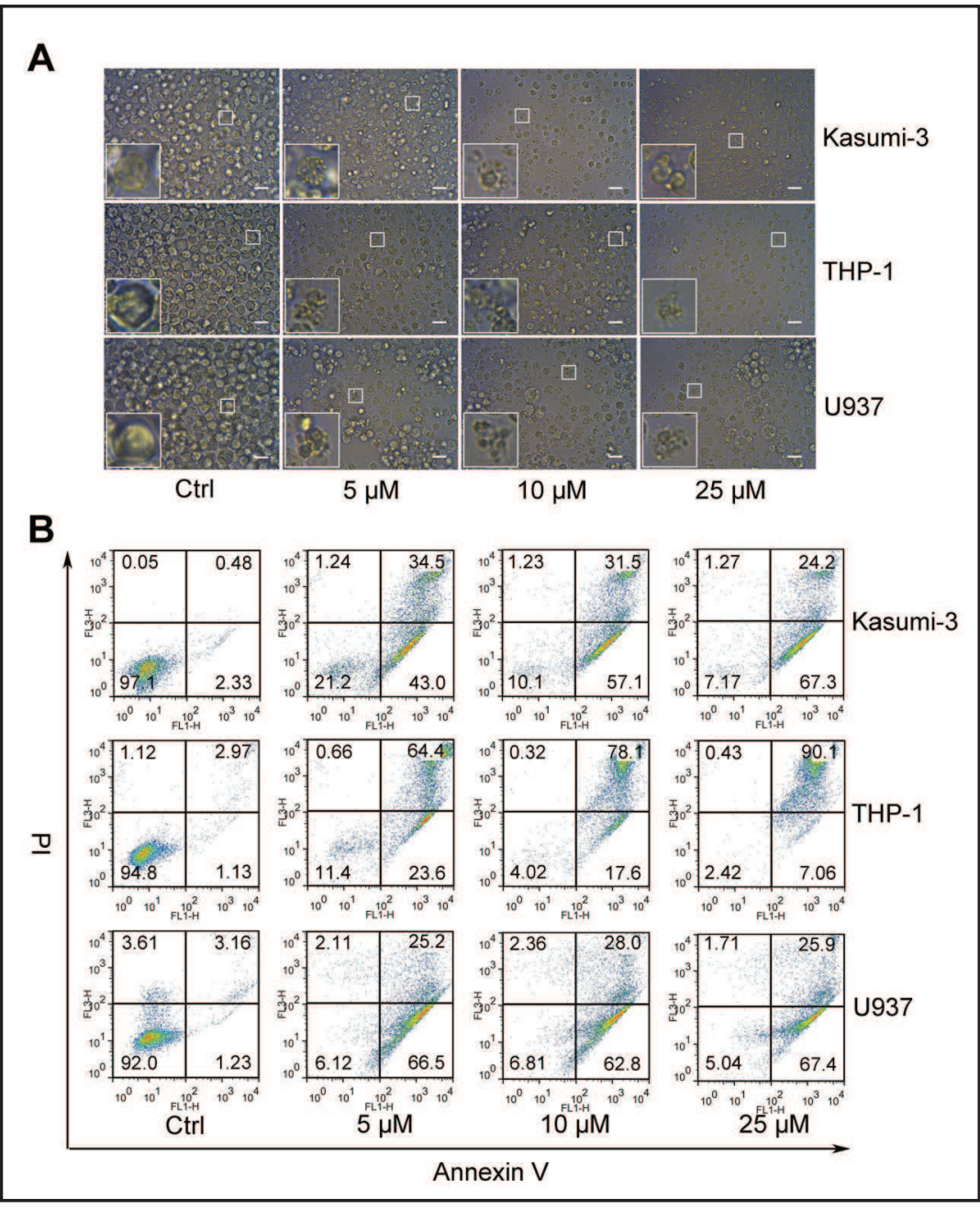

TPEN induces apoptosis of NB4 cells through inhibiting intracellular nitric oxide (NO) signaling

The crosstalk between $\mathrm{Zn}^{2+}$ and NO signaling has been reported to play key roles in apoptosis of neurons [34]. We were interested in whether NO signaling regulates survival or apoptosis of NB4 APL cells during zinc depletion. Using the fluorescence probe DAF-FM DA, we found that TPEN induced apoptosis of NB4 APL cells with attenuated intracellular NO 


\section{Cellular Physiology Cell Physiol Biochem 2017;42:1822-1836 \begin{tabular}{ll|l}
\hline DOI: 10.1159/000479539 & $\begin{array}{l}\text { () } 2017 \text { The Author(s). Published by S. Karger AG, Basel } \\
\text { www.karger.com/cpb }\end{array}$ \\
\hline
\end{tabular}}

Fig. 6. TPEN induces apoptosis of NB4 cells with decreased intracellular ROS. (A) NB4 cells treated with $5 \mu \mathrm{M}$ TPEN or vehicle were stained with DCFH-DA for ROS measurement. (B) Apoptosis rate of NB4 cells treated with TPEN with or without the presence of NAC was estimated by flow cytometry employing Annexin V/PI staining. (C) Cell morphology was observed and recorded using an optical microscope. The scale bar represents $20 \mu \mathrm{m}$. A partially enlarged view was shown in the lower left corner of every picture. Data are represented as mean \pm SD. ${ }^{* * *} P<0.005$ compared with the vehicle control.

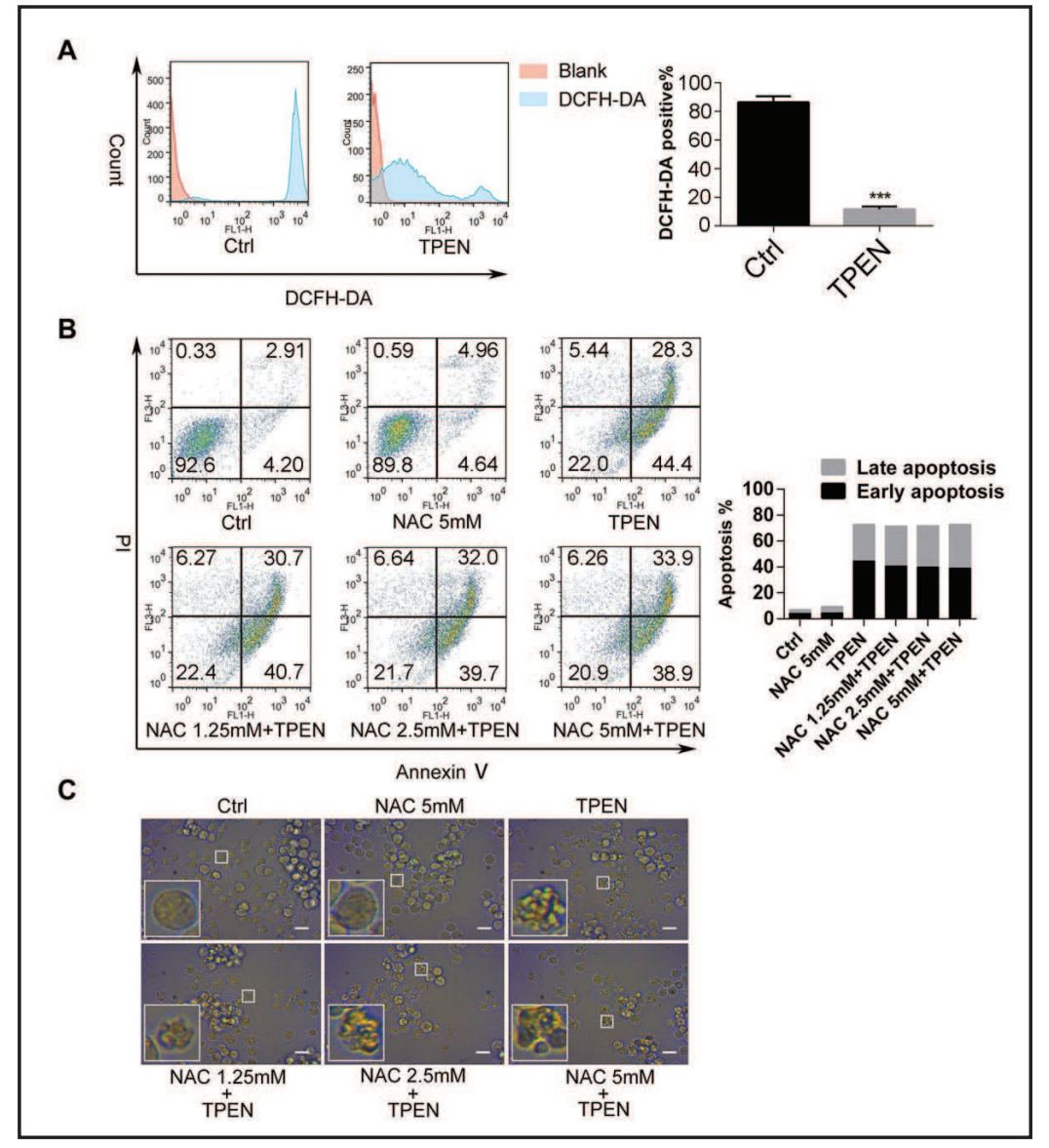

signaling (Fig. 7A). Next, we treated NB4 cells with TPEN with or without SNP (a NO donor) or C-PTIO (a NO scavenger), and measured the intracellular NO level. It was found that SNP effectively reversed the decrease in NO caused by TPEN. In contrast, C-PTIO suppressed intracellular NO signaling with or without TPEN (Fig. 7A). Next, we further revealed that SNP pre-incubation rescued NB4 cells from TPEN-triggered apoptosis, whereas C-PTIO showed cytoxixity to NB4 cells, and enhanced the pro-apoptotic effect of TPEN (Fig. 7B-D). Apoptosis rate was determined with Annexin V/PI staining by flow cytometry (Fig. 7B). Typical apoptotic signs of cellular morphology was observed under an optical microscope (Fig. 7C). Activation and cleavage of caspase-8, -9 and-3 was confirmed by western blot (Fig. 7D). These data suggest that TPEN induces apoptosis in NB4 cells at least partially via suppressing intracellular NO signaling.

Exogenous zinc supplement at $5 \mu M$ has no obvious effect on intracellular NO signaling and survival of NB4 cells

To further scrutinize the crosstalk of intracellular labile zinc signaling and NO signaling on survival and apoptosis of NB4 APL cells, we first treated NB4 cells with $5 \mu \mathrm{M}$ zinc sulfate for $24 \mathrm{~h}$ in the absence of TPEN, and detected a slight increase in intracellular labile zinc signaling (Fig. 8A). No obvious changes in intracellular nitric oxide signaling or cell viability was observed (Fig. 8B-D).

Zinc supplement reverses reduction of intracellular NO signaling in NB4 cells in zinc depletion condition caused by TPEN

We further treated NB4 cells with $5 \mu \mathrm{M}$ TPEN with or without the presence of indicated concentrations of exogenous $\mathrm{Zn}^{2+}(0-5 \mu \mathrm{M}$, pre-incubated for another $2 \mathrm{~h})$ for $24 \mathrm{~h}$, and detected intracellular NO level with DAF-FM DA by flow cytometry. We found that exogenous 


\section{Cellular Physiology Cell Physiol Biochem 2017;42:1822-1836 \begin{tabular}{ll|l} 
and Biochemistry & $\begin{array}{l}\text { DOI: 10.1159/000479539 } \\
\text { Published online: July 27, } 2017\end{array}$ & $\begin{array}{l}\text { @ } 2017 \text { The Author(s). Published by S. Karger AG, Basel } \\
\text { www.karger.com/cpb }\end{array}$ \\
\hline
\end{tabular}

Fig. 7. TPEN triggers apoptosis of NB4 cells through deregulating intracellular NO signaling. (A) NB4 cells were treated with $5 \mu \mathrm{M}$ TPEN in the presence or absence of SNP (500 $\mu \mathrm{M}$, pre-incubated for $2 \mathrm{~h}$ ) or C-PTIO $(50 \mu \mathrm{M}$, pre-incubated for 2 h) for $24 \mathrm{~h}$. Intracellular nitric oxide was monitored using the fluorescence probe DAF-FM DA. The results are represented as percentage of DAFFM DA-positive cells. (B) Apoptosis was measured with Annexin V/PI dual staining by flow cytometry, and morphological changes of NB4 cells were observed and recorded using an optical microscope (C). The scale bar represents $20 \mu \mathrm{m}$. A partially enlarged view was shown in the lower left corner of every picture. Western blot analysis was conducted to determine protein expression of caspase- 3 , caspase- 8 and caspase- 9 in NB4 cells treated with TPEN $(5 \mu \mathrm{M})$ in the presence or absence of SNP $(500 \mu \mathrm{M})$ or C-PTIO $(50 \mu \mathrm{M})$ for 24 h (D). All experiments were done at least in three independent replicates and data were shown as mean \pm SD. ${ }^{*} P<0.05$ and ${ }^{* * *} P<0.005$.

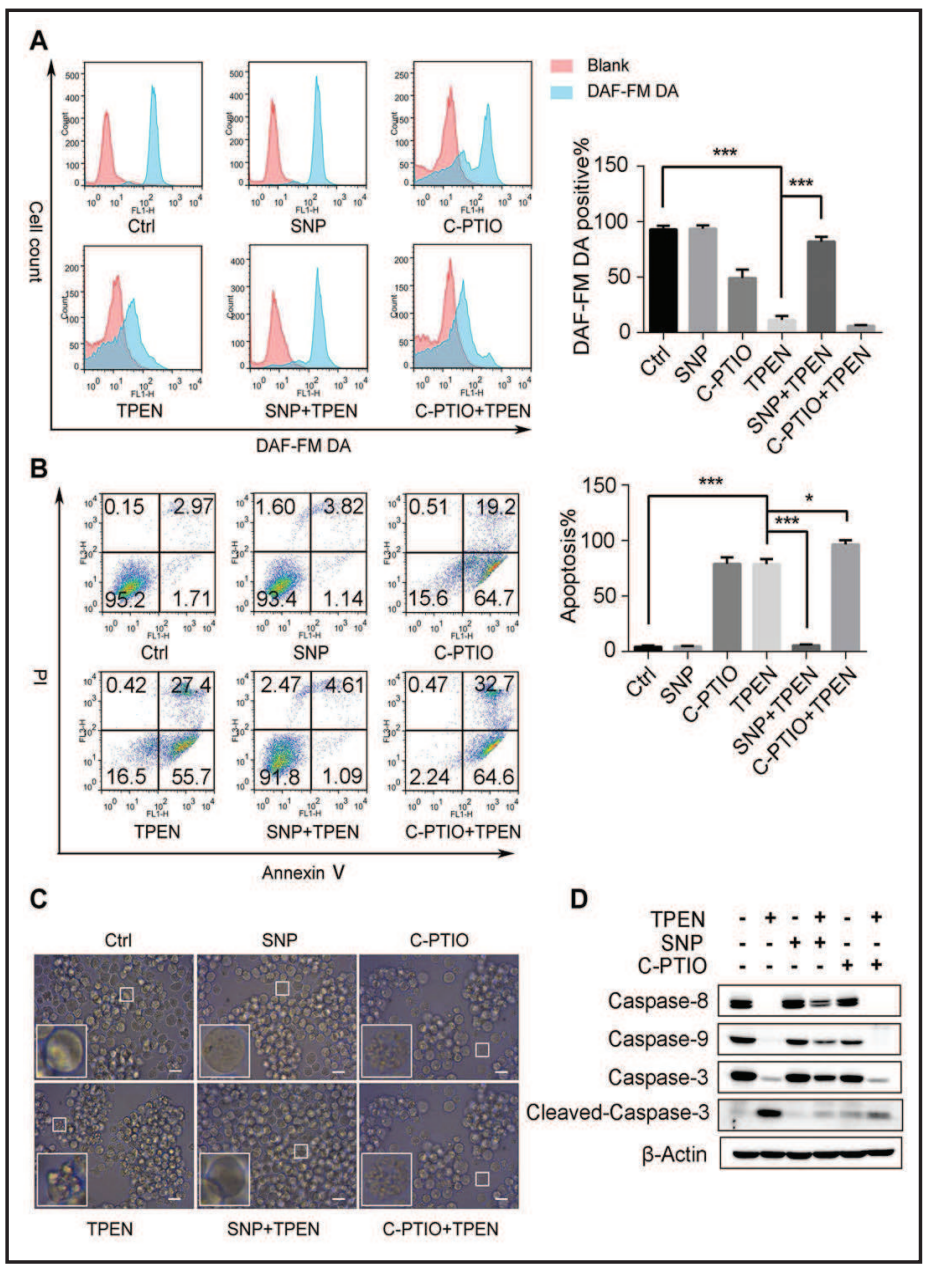

$\mathrm{Zn}^{2+}$ supplement reversed the reduction of NO signaling in TPEN-treated NB4 cells in a concentration-dependent manner (Fig. 9A-B).

\section{Zinc supplement rescues NB4 cells from TPEN-triggered apoptosis}

It has been previously reported that TPEN induces apoptosis in human ALL cells independently of its zinc-chelating ability [38]. To assess the role of zinc depletion in TPENtriggered apoptosis, we measured the apoptosis rate in NB4 APL cells treated with TPEN with or without the presence of indicated concentrations of exogenous zinc. We demonstrated that exogenous zinc supplement efficiently reversed zinc depletion caused by TPEN and rescued NB4 cells from TPEN-triggered apoptosis in a dosage-dependent way (Fig. 10A-D). These data indicate that TPEN induces apoptosis of NB4 APL cells through its zinc-chelating activity.

The NO donor SNP reverses TPEN-triggered zinc depletion in a concentration-dependent manner

Nitric oxide has been reported to promote zinc release from its intracellular storage in neurons [39]. We are interested in the effects of intracellular NO signaling on $\mathrm{Zn}^{2+}$ signaling in NB4 APL cells during zinc depletion. Therefore, we treated NB4 cells with TPEN with or without SNP or C-PTIO at indicated concentrations, and measured intracellular labile $\mathrm{Zn}^{2+}$ level with the fluorescent sensor Zinpyr-1 by flow cytometry. We found that SNP reversed TPEN-triggered zinc depletion in a concentration-dependent way. In contrast, C-PTIO further aggravated zinc depletion caused by TPEN (Fig. 11). Our data suggest that NO signaling plays 


\section{Cellular Physiology Cell Physiol Biochem 2017;42:1822-1836

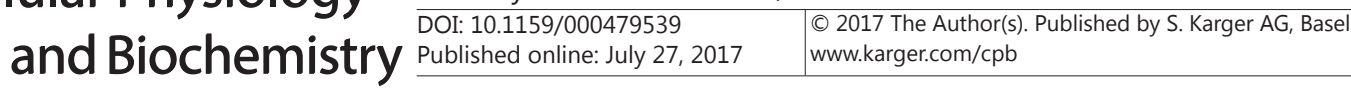 \\ Zhu et al.: TPEN Induces Apoptosis in NB4 Cells}

Fig. 8. Exogenous zinc supplement at 5 $\mu \mathrm{M}$ has no obvious effects on intracellular nitric oxide signaling and apoptosis of NB4 cells. NB4 cells were treated with $5 \mu \mathrm{M}$ zinc sulfate, and intracellular labile $\mathrm{Zn}^{2+}$ signaling was monitored using the specific fluorescent probe Zinpyr-1 by flow cytometry. Relative intracellular labile zinc level was expressed by the relative geometric mean fluorescence intensity of Zinpyr-1 (A). Apoptosis of NB4 cells treated with or without zinc sulfate was probed with Annexin V/PI dual staining by flow cytometry (B). The morphology of NB4 cells was observed and recorded using an optical microscope (C). The scale bar represents $20 \mu \mathrm{m}$. A partially enlarged view was shown in the lower left corner of every picture. Intracellular nitric oxide was monitored using the fluorescence probe DAF-FM DA. The results are represented as the percentage of DAF-FM DA-positive cells (D). Experiments were performed in triplicates. Data are represented as mean \pm SD. ${ }^{*} P<0.05$ compared with vehicle-treated cells.

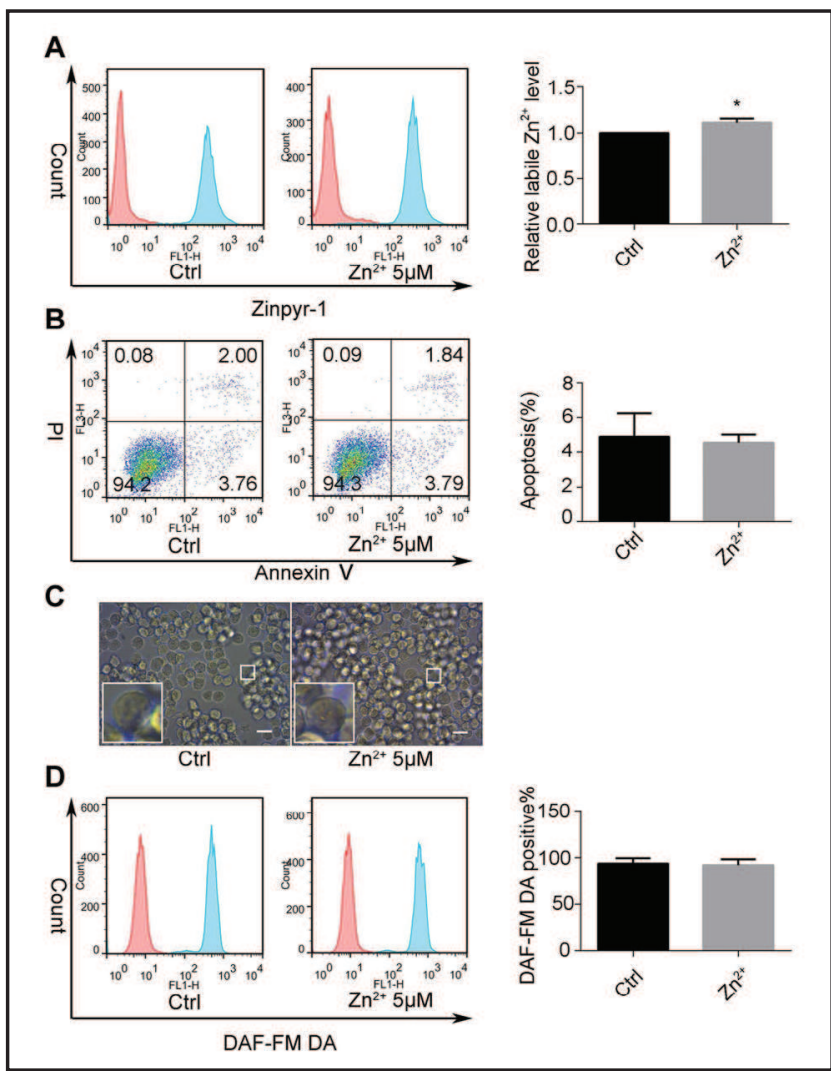

Fig. 9. Attenuation of intracellular NO signaling caused by TPEN can be reversed by exogenous zinc supplement. NB4 cells were treated with $5 \mu \mathrm{M}$ TPEN for $24 \mathrm{~h}$ with or without the presence of indicated concentrations of zinc sulfate $(0-5 \mu \mathrm{M})$, in-

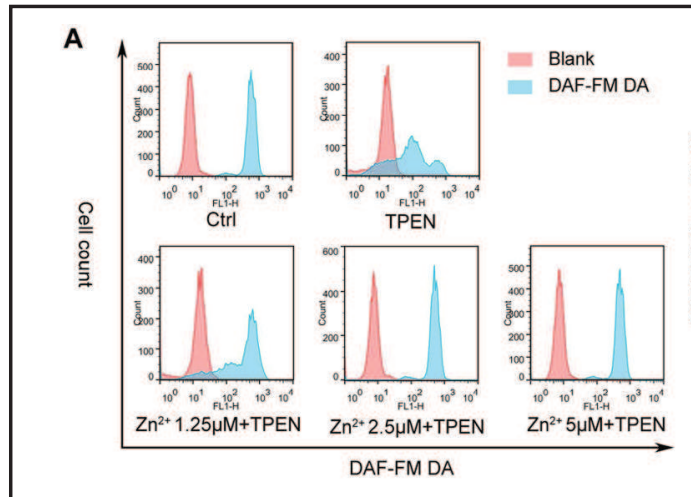
B tracellular nitric oxide was monitored using the fluorescence probe DAF-FM DA by flow cytometry (A). The results are represented as the percentage of DAF-FM DA-positive cells (B). Data were represented as mean $\pm \mathrm{SD}$ of three independent experiments. ${ }^{* *} P<0.01$ and ${ }^{* * *} P<0.005$.

important roles in regulating $\mathrm{Zn}^{2+}$ signaling and in zinc depletion-triggered apoptosis in NB4 APL cells.

\section{Discussion}

New targets and therapy strategies against leukemia are still of intense interest [4042]. Zinc plays dual roles in regulating cell proliferation and apoptosis. In vitro cytotoxicity of zinc towards solid tumor cells, especially prostate [43] or breast cancer cells [44], has been widely reported. Recently, apoptosis induced by zinc depletion was also recognized as a potential therapeutic strategy against cancer $[45,46]$. However, the role of zinc signaling in 


\section{Cellular Physiology Cell Physiol Biochem 2017;42:1822-1836

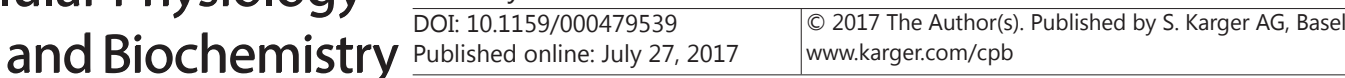

Fig. 10. Exogenous zinc supplement reverses decrease in intracellular labile $\mathrm{Zn}^{2+}$ signaling and rescued NB4 cells from apoptosis caused by TPEN. (A) NB4 cells were pre-incubated with indicated concentrations of zinc sulfate (0-5 $\mu \mathrm{M})$ for $2 \mathrm{~h}$, and then treated with $5 \mu \mathrm{M}$ TPEN for another $24 \mathrm{~h}$. Relative labile zinc level was measured using the specific fluorescent probe Zinpyr-1 by flow cytometry, and expressed by the relative geometric mean fluorescence intensity of Zinpyr-1. Apoptosis was monitored with Annexin V/PI dual staining by flow cytometry (B). The morphology of NB4 cells was observed and recorded using an optical microscope (C). Scale bar: 20 $\mu \mathrm{m}$. A partially enlarged view was shown in the lower left corner of every picture. (D) Western blot analysis of caspase-8,-9 and -3 expression in NB4 cells treated with TPEN $(5 \mu \mathrm{M})$ alone or with the presence of zinc sulfate $(2.5 \mu \mathrm{M})$

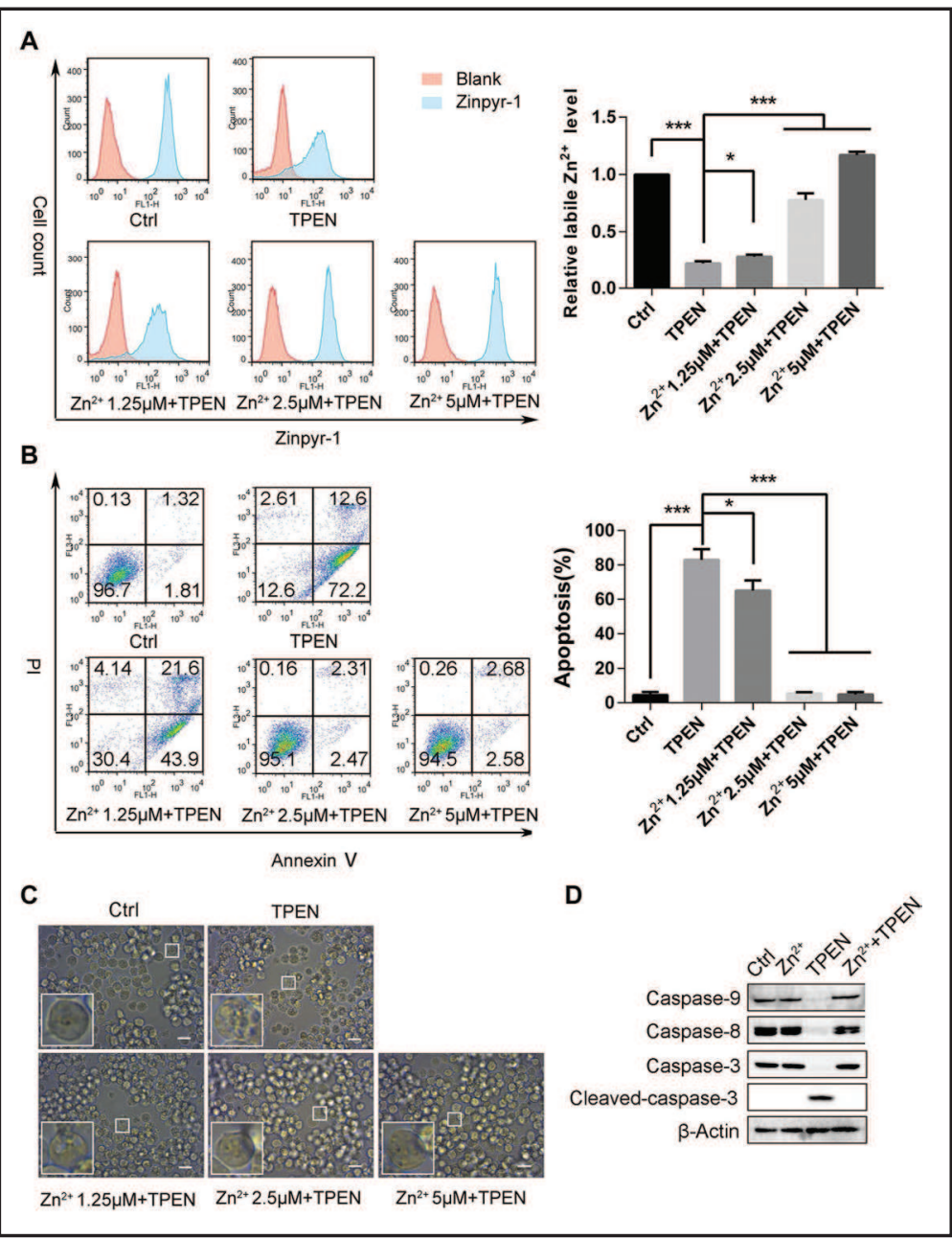

for $24 \mathrm{~h}$. $\beta$-Actin served as a loading control. Experiments were performed in triplicates, and representative blots were shown. Data are represented as mean \pm SD. ${ }^{*} P<0.05$, ${ }^{* * *} P<0.005$ compared with vehicle-treated cells.

Fig. 11. The nitric oxide donor SNP attenuates TPEN-triggered zinc depletion status of NB4 cells. NB4 cells were treated with $5 \mu \mathrm{M}$ TPEN for $24 \mathrm{~h}$ with or without indicated concentrations of SNP $(0,250$ or $500 \mu \mathrm{M})$ or C-PTIO $(0$, $12.5,25$ or $50 \mu \mathrm{M}$ ), and then intracellular labile zinc was measured using Zinpyr-1 by flow cytometry. Labile $\mathrm{Zn}^{2+}$ level was represented as relative geometric mean fluorescence intensity of Zinpyr-1. Data were represented as mean \pm SD of three independent experiments. ${ }^{* *} P<0.01,{ }^{* * *} P<0.005$.

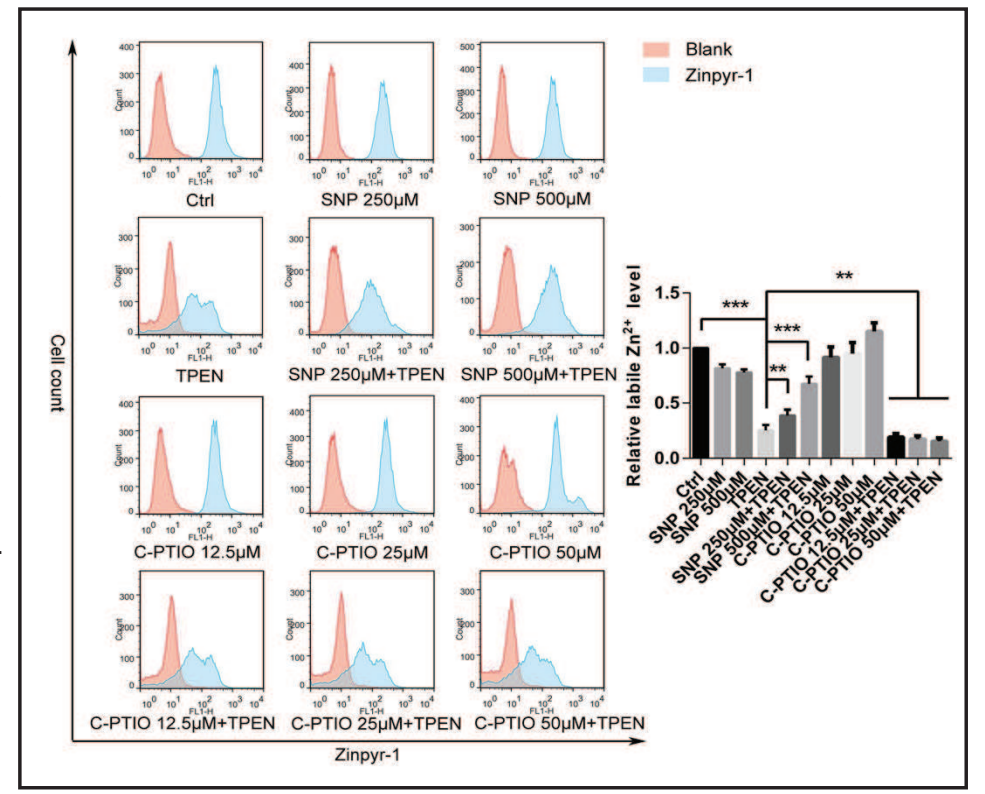




\section{Cellular Physiology Cell Physiol Biochem 2017;42:1822-1836

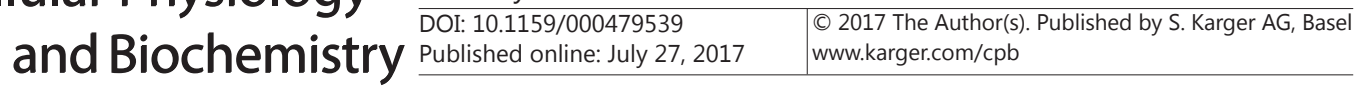 Zhu et al.: TPEN Induces Apoptosis in NB4 Cells}

regulating survival or apoptosis of leukemia cells remains unclear. The work presented here demonstrates a pro-apoptotic effect of the zinc chelator TPEN on NB4 APL cells.

Hashemi et al. demonstrate that intracellular zinc depletion by TPEN induces apoptosis in breast cancer lines via the intrinsic pathway with the activation of caspase-9 not caspase-8 [47]. In the present study, although cleavage and activation of caspase-8, -9 and-3 were observed, TPENinduced apoptosis in NB4 cells was blocked by pan-caspase inhibitors, but not by caspase-8 inhibitors. These data indicated that TPEN triggered apoptosis in NB4 APL cells mainly via the intrinsic pathway not the extrinsic pathway, consistently with TPEN-

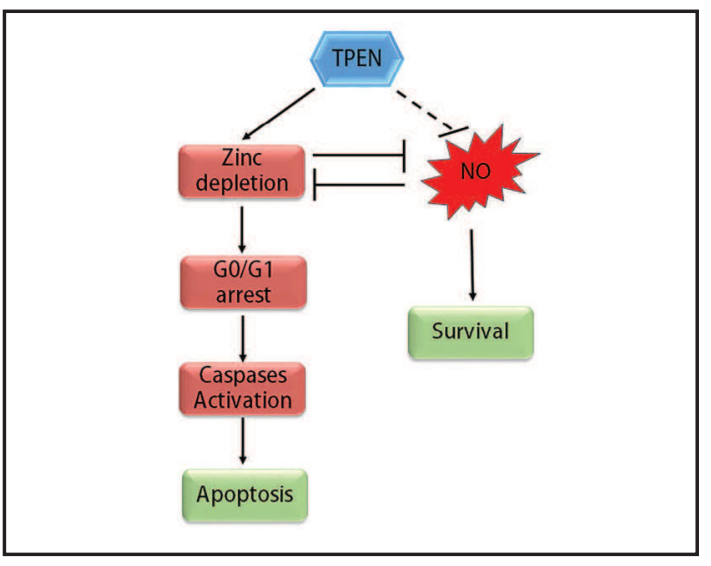

Fig. 12. Schematic representation of the mechanism responsible for TPEN-induced apoptosis in NB4 APL cells.

induced apoptosis in breast cancer cells. It has been reported that caspase- 8 activation is regulated by caspase- 9 activation in 1-methyl-4-phenyl-1, 2, 3, 6-tetrahydropyridine-induced Parkinson's disease [48]. Similarly, we believe that caspase-8 activation is most probably the by-product effect of caspase- 9 activation in TPEN-triggered apoptosis in NB4 cells.

As a specific chelator of zinc, the pro-apoptotic effects of TPEN have been reported on several types of cells, including neuronal cells [49], prostate cancer cells [50], colon cancer cell [46], hepatocellular carcinoma cells [51] and breast cancer cells [52]. Mechanisms responsible for TPEN's cytotoxicity vary in different cancer cell lines. TPEN has been reported to induce apoptosis of colon cancer cells via excessive ROS production and DNA damage [46]. Hashemi et al. demonstrate that TPEN-triggered apoptosis in MCF-7 and MDA-MB468 breast cancer cells can be reversed by the ROS scavenger NAC [47]. Juriol et al. demonstrate that zinc deficiency induces NADPH oxidase-dependent superoxide anion production and increases antioxidant enzymes activity in cardiac tissue of male rats [53]. Recently, Mendivilperez et al. demonstrate that TPEN induces apoptosis of acute lymphoblastic leukemia (ALL) cells independently of its zinc chelating activity. Instead, it causes elevated oxidative stress [38]. In contrast, Matias et al. demonstrate that zinc chelation by TPEN mediates the lysosomal disruption and induces apoptosis without ROS production in human neuroblastoma SHSY5Y cells [54]. It has also been reported that zinc overload increases ROS production and induces senescence in vascular smooth muscle cells [55]. These studies indicate that the responsiveness of ROS to zinc dyshomeostasis differs in different cells. As demonstrated here, we found that TPEN triggered apoptosis of human acute promyelocytic NB4 cells with decreased intracellular ROS levels. We further found that TPEN-triggered apoptosis in NB4 APL cells could not be reversed by NAC addition. Basal intracellular ROS and zinc level in NB4 cells might partially affect this process, but the specific details of decreased ROS production mechanism in response to TPEN exposure require further study. We also found that exogenous zinc supplement prevented TPEN-triggered apoptosis in NB4 APL cells, indicating the importance of its zinc-chelating activity in this process. These results suggest that TPEN may induce apoptosis of NB4 APL cells by a different mechanism from ALL cells.

Nitric oxide (NO) is another reactive molecule whose signaling has been shown to regulate survival and apoptosis in different cells [56,57]. Zinc signaling has been reported to regulate iNOS expression and activity in keratinocytes [58] and aortic endothelial cells [59]. The crosstalk between $\mathrm{NO}$ and $\mathrm{Zn}^{2+}$ signaling in leukemia cells still remains to be elaborated. Although excessive NO is cytotoxic to cancer cells [27], physiological level of intracellular NO is essential for cell survival and proliferation [60]. Recently, Juriol et al. demonstrate that zinc deficiency activates apoptotic and inflammatory processes with decreased nitric oxide synthase activity in cardiac tissue of rats [53]. In the present study, we found that TPEN induces apoptosis of NB4 APL cells by downregulating intracellular NO signaling. We 


\section{Cellular Physiology Cell Physiol Biochem 2017;42:1822-1836 \begin{tabular}{ll|l} 
and Biochemistry & $\begin{array}{l}\text { DOI: 10.1159/000479539 } \\
\text { Published online: July 27, } 2017\end{array}$ & $\begin{array}{l}\text { ( ) 2017 The Author(s). Published by S. Karger AG, Basel } \\
\text { www.karger.com/cpb }\end{array}$ \\
\hline
\end{tabular} \\ Zhu et al.: TPEN Induces Apoptosis in NB4 Cells}

further showed that exogenous zinc supplement reversed the attenuation in NO signaling and rescued NB4 cells from apoptosis under zinc depletion status, although zinc supplement at the same dosage has no obvious regulatory effects on intracellular NO signaling in normal NB4 cells in the absence of TPEN. All these results suggest that NO signaling plays protective roles in apoptosis of NB4 cells caused by zinc depletion.

Nitric oxide has been reported to promote the release of intracellular $\mathrm{Zn}^{2+}$ from zinc sulfur clusters in various cell types including lung fibroblasts [61], neurons [34], and endothelial cells [62]. In our study, we demonstrated that the NO donor SNP promoted intracellular labile zinc signaling in NB4 cells under zinc depletion status caused by TPEN, whereas the NO scavenger C-PTIO inhibited zinc signaling. In the absence of the zinc chelator TPEN, no significant regulatory effect of SNP or C-PTIO on labile zinc signaling in NB4 cells was detected. These results further verify the function of NO signaling in upregulating labile zinc signaling and reducing apoptosis in NB4 APL cells under zinc depletion status.

In summary, we reported the apoptogenic capability of the zinc chelator TPEN in NB4 APL cells, where its cytotoxicity is mediated by suppressing intracellular labile zinc signaling and NO signaling (Fig. 12). Our in vitro data suggest that zinc depletion by TPEN may be a potential therapeutic strategy against APL.

\section{Acknowledgements}

This investigation was financially funded by the project of the National Natural Science Foundation of China (81630092, 81421091), National Key Research Project (2016YFC0902700,2014CB744501),ShenzhenScienceand Technology Innovation Committee (JCYJ20160331152141936) and Shenzhen Peacock Plan (KQTD20140630165057031).

\section{Disclosure Statement}

The authors declare no conflict of interest.

\section{References}

1 Wang X, Wang Y: Ginsenoside Rh2 Mitigates Pediatric Leukemia Through Suppression of Bcl-2 in Leukemia Cells. Cell Physiol Biochem 2015;37:641-650.

-2 Trivedi R, Muller GA, Rathore MS, Mishra DP, Dihazi H: Anti-Leukemic Activity of Shikonin: Role of ERP57 in Shikonin Induced Apoptosis in Acute Myeloid Leukemia. Cell Physiol Biochem 2016;39:604-616.

- Kakizuka A, Miller WH, Jr., Umesono K, Warrell RP, Jr., Frankel SR, Murty VV, Dmitrovsky E, Evans RM: Chromosomal translocation $\mathrm{t}(15 ; 17)$ in human acute promyelocytic leukemia fuses RAR alpha with a novel putative transcription factor, PML. Cell 1991;66:663-674.

-4 Testa U, Lo-Coco F: Prognostic factors in acute promyelocytic leukemia: strategies to define high-risk patients. Ann Hematol 2016;95:673-680.

-5 Wang ZY, Chen Z: Acute promyelocytic leukemia: from highly fatal to highly curable. Blood 2008;111:25052515.

6 Lallemand-Breitenbach V, Zhu J, Chen Z, de The H: Curing APL through PML/RARA degradation by As203. Trends Mol Med 2012;18:36-42.

7 Chen ZX, Xue YQ, Zhang R, Tao RF, Xia XM, Li C, Wang W, Zu WY, Yao XZ, Ling BJ: A clinical and experimental study on all-trans retinoic acid-treated acute promyelocytic leukemia patients. Blood 1991;78:1413-1419.

-8 Elemam 0, Abdelmoety D: Acute promyelocytic leukemia, study of predictive factors for Differentiation Syndrome, single center experience. J Egypt Natl Canc Inst 2013;25:13-19.

-9 Iland HJ, Bradstock K, Supple SG, Catalano A, Collins M, Hertzberg M, Browett P, Grigg A, Firkin F, Hugman A: All-trans-retinoic acid, idarubicin, and IV arsenic trioxide as initial therapy in acute promyelocytic leukemia (APML4). Blood 2012;120:1570-1580. 


\section{Cellular Physiology Cell Physiol Biochem 2017;42:1822-1836 \begin{tabular}{ll|l} 
DOI: 10.1159/000479539 & $\begin{array}{l}\text { () 2017 The Author(s). Published by S. Karger AG, Basel } \\
\text { www.karger.com/cpb }\end{array}$
\end{tabular}}

Zhu et al.: TPEN Induces Apoptosis in NB4 Cells

10 Goto E, Tomita A, Atsumi A, Kiyoi H, Naoe T: Double Genetic Mutations in PML-Rara Fusion Gene Confirmed in a Patient Showing Resistance to All-Trans Retinoic Acid and Arsenic-Trioxide Therapy. Blood 2009;114:693-693.

11 Singh H, Werner L, Deangelo D, Ballen K, Amrein P, Wadleigh M, Neuberg D, Fox E, Stone R, Attar E: Clinical outcome of patients with acute promyelocytic leukemia and FLT3 mutations. Am J Hematol 2010;85:956957.

12 Lee JJ, Cho D, Chung IJ, Cho SH, Park KS, Park MR, Ryang DW, Kim HJ: CD34 expression is associated with poor clinical outcome in patients with acute promyelocytic leukemia. Am J Hematol 2003;73:149-153.

13 Zhang X, Zhao Y, Chu Q, Wang ZY, Li H, Chi ZH: Zinc modulates high glucose-induced apoptosis by suppressing oxidative stress in renal tubular epithelial cells. Biol Trace Elem Res 2014;158:259-267.

14 Xiao D, Wei H, Liang J, Feng P: Abstract 4856: Zinc-induced autophagy in prostate cancer cells is associated with cell death. Cancer Res 2011;70:4856.

15 Bao B, Prasad AS, Beck FWJ, Bao GW, Singh T, Ali S, Sarkar FH: Intracellular free zinc up-regulates IFN- $\gamma$ and T-bet essential for Th 1 differentiation in Con-A stimulated HUT-78 cells. Biochem Biophys Res Commun 2011;407:703-707.

-16 Xue J, Wang S, Wu J, Hannafon BN, Ding WQ: Zinc at Sub-Cytotoxic Concentrations Induces Heme Oxygenase-1 Expression in Human Cancer Cells. Cell Physiol Biochem 2013;32:100-110.

17 Passerini A, Andreini C, Menchetti S, Rosato A, Frasconi P: Predicting zinc binding at the proteome level. BMC Bioinformatics 2007;8:39.

18 Franklin RB: The status of zinc in the development of hepatocellular cancer. Cancer Biol Ther 2014;15:353360.

19 Wu X, Tang J, Xie M: Serum and hair zinc levels in breast cancer: a meta-analysis. Sci Rep 2015;5:12249.

20 Iitaka M, Kakinuma S, Fujimaki S, Oosuga I, Fujita T, Yamanaka K, Wada S, Katayama S: Induction of apoptosis and necrosis by zinc in human thyroid cancer cell lines. J Endocrinol 2001;169:417-424.

21 Franklin R, Costello L: Zinc as an anti-tumor agent in prostate cancer and in other cancers. Arch Biochem Biophys 2007;463:211-217.

-22 Bacher RF: A Review of the Current Status and Concept of the Emerging Implications of Zinc and Zinc Transporters in the Development of Pancreatic Cancer. Pancreat Disord Ther 2013;Suppl 4:2-4.

23 Makhov P, Golovine K, Uzzo RG, Rothman J, Crispen PL, Shaw T, Scoll BJ, Kolenko VM: Zinc chelation induces rapid depletion of the X-linked inhibitor of apoptosis (XIAP) and sensitizes prostate cancer cells to TRAILmediated apoptosis. Cell Death Differ 2008;15:1745-1751.

24 Donadelli M, Pozza ED, Costanzo C, Scupoli MT, Scarpa A, Palmieri M: Zinc depletion efficiently inhibits pancreatic cancer cell growth by increasing the ratio of antiproliferative/proliferative genes. J Cell Biochem 2008;104:202-212.

25 Zuo XL, Chen JM, Zhou X, Li XZ, Mei GY: Levels of selenium, zinc, copper, and antioxidant enzyme activity in patients with leukemia. Biol Trace Elem Res 2006;114:41-53.

-26 Sgarbieri UR, Fisberg M, Tone LG, Latorre MR: Nutritional assessment and serum zinc and copper concentration among children with acute lymphocytic leukemia: a longitudinal study. Sao Paulo Med J 2006;124:316-320.

27 Bonavida B, Garban H: Nitric oxide-mediated sensitization of resistant tumor cells to apoptosis by chemoimmunotherapeutics. Redox Biol 2015;6:486-494.

28 Cheng H, Wang L, Mollica M, Re AT, Wu S, Zuo L: Nitric oxide in cancer metastasis. Cancer Lett 2014;353:17.

29 Zhu T, Yao Q Wang W, Yao H, Chao J: iNOS Induces Vascular Endothelial Cell Migration and Apoptosis Via Autophagy in Ischemia/Reperfusion Injury. Cell Physiol Biochem 2016;38:1575-1588.

-30 Martinez L, Thames E, Kim J, Chaudhuri G, Singh R, Pervin S: Increased sensitivity of African American triple negative breast cancer cells to nitric oxide-induced mitochondria-mediated apoptosis. BMC Cancer 2016;16:559.

31 Calabrese V, Cornelius C, Rizzarelli E, Owen JB, Dinkova-Kostova AT, Butterfield DA: Nitric oxide in cell survival: a janus molecule. Antioxid Redox Signal 2009;11:2717-2739.

-32 Bhowmick R, Girotti AW: Pro-Survival and Pro-Growth Effects of Stress-Induced Nitric Oxide in a Prostate Cancer Photodynamic Therapy Model. Cancer Lett 2014;343:115-122.

-33 Bian K, Murad F: What is next in nitric oxide research? From cardiovascular system to cancer biology. Nitric Oxide 2014;43:3-7. 


\section{Cellular Physiology Cell Physiol Biochem 2017;42:1822-1836 \begin{tabular}{l|l|l}
\hline DOI: 10.1159/000479539 & $\begin{array}{l}\text { C 2017 The Author(s). Published by S. Karger AG, Basel } \\
\text { www.karger.com/cpb }\end{array}$ \\
\hline
\end{tabular}}

Zhu et al.: TPEN Induces Apoptosis in NB4 Cells

-34 Bossy-Wetzel E, Talantova MV, Lee WD, Schölzke MN, Harrop A, Mathews E, Götz T, Han J, Ellisman MH, Perkins GA: Crosstalk between Nitric Oxide and Zinc Pathways to Neuronal Cell Death Involving Mitochondrial Dysfunction and p38-Activated $\mathrm{K}^{+}$Channels. Neuron 2004;41:351-365.

35 Malavolta M, Costarelli L, Giacconi R, Muti E, Bernardini G, Tesei S, Cipriano C, Mocchegiani E: Single and three-color flow cytometry assay for intracellular zinc ion availability in human lymphocytes with Zinpyr-1 and double immunofluorescence: Relationship with metallothioneins. Cytometry A 2006;69A:1043-1053.

-36 Wu XL, Feng XF, Zhao XQ Ma FT, Liu N, Guo HM, Li CN, Du H, Zhang BX: Role of Beclin-1-Mediated Autophagy in the Survival of Pediatric Leukemia Cells. Cell Physiol Biochem 2016;39:1827-1836.

-37 Fan JP, Wang YQ, Wang XB, Wang P, Tang W, Yuan WJ, Kong LL, Liu QH: The Antitumor Activity of Meconopsis Horridula Hook, a Traditional Tibetan Medical Plant, in Murine Leukemia L1210 Cells. Cell Physiol Biochem 2015;37:1055-1065.

-38 Mendivil-Perez M V-PC, Jimenez-Del-Rio M: TPEN induces apoptosis independently of zinc chelator activity in a model of acute lymphoblastic leukemia and ex vivo acute leukemia cells through oxidative stress and mitochondria caspase-3- and AIF-dependent pathways. Oxid Med Cell Longev DOI:10.1155/2012/313275.

-39 Berendji D, Kolb-Bachofen V, Meyer KL, Grapenthin O, Weber H, Wahn V, Kröncke KD: Nitric oxide mediates intracytoplasmic and intranuclear zinc release. FEBS Lett 1997;405:37-41.

40 Han J, Lin M, Zhou DF, Zhang ZQ Jin RM, Zhou F: Huang Qi Huai Granules Induce Apoptosis in Acute Lymphoblastic Leukemia Cells through the Akt/Fox01 Pathway. Cell Physiol Biochem 2016;38:1803-1814.

41 Long B, Wang LX, Zheng FM, Lai SP, Xu DR, Hu Y, Lin DJ, Zhang XZ, Dong L, Long ZJ: Targeting GLI1 Suppresses Cell Growth and Enhances Chemosensitivity in CD34+ Enriched Acute Myeloid Leukemia Progenitor Cells. Cell Physiol Biochem 2016;38:1288-1302.

42 Lu L, Wang F, He L, Xue Y, Wang Y, Zhang H, Rong L, Wang M, Zhang Z, Fang Y: Interaction Between IGF1 Polymorphisms and the Risk of Acute Lymphoblastic Leukemia in Chinese Children. Cell Physiol Biochem 2015;36:1346-1358.

-43 Ku JH, Seo SY, Kwak C, Kim HH: The role of survivin and Bcl-2 in zinc-induced apoptosis in prostate cancer cells. Urol Oncol 2010;30:562-568.

44 Alsaran N, Subashbabu P, Alnouri DM, Alfawaz HA, Alshatwi AA: Zinc enhances CDKN2A, pRb1 expression and regulates functional apoptosis via upregulation of p53 and p21 expression in human breast cancer MCF-7 cell. Environ Toxicol Pharmacol 2016;47:19-27.

-45 Carraway RE, Dobner PR: Zinc pyrithione induces ERK- and PKC-dependent necrosis distinct from TPENinduced apoptosis in prostate cancer cells. BBA - Mol Cell Res 2012;1823:544-557.

46 Galimuhtasib H, Rahal O, Fatfat M, Hankache C, Osman B, Khalife H, Machaca K: Abstract 2564: The anticancer molecule TPEN induces DNA damage in human colon cancer cells. Cancer Res 2015;75:25642564.

47 Hashemi M, Ghavami S, Eshraghi M, Booy EP, Los M: Cytotoxic effects of intra and extracellular zinc chelation on human breast cancer cells. Eur J Pharmacol 2007;557:9-19.

-48 Viswanath V, Wu YQ Boonplueang R, Chen S, Stevenson FF, Yantiri F, Yang LC, Beal MF, Andersen JK: Caspase-9 activation results in downstream caspase-8 activation and bid cleavage in 1-methyl-4-phenyl1,2,3,6-tetrahydropyridine-induced Parkinson's disease. J Neurosci 2001;21:9519-9528.

49 Ra H, Kim HL, Lee HW, Kim YH: Essential role of p53 in TPEN-induced neuronal apoptosis. FEBS Lett 2009;583:1516-1520.

-50 Gmeiner WH, Boyacioglu 0, Stuart CH, Jennings-Gee J, Balaji KC: The cytotoxic and pro-apoptotic activities of the novel fluoropyrimidine F10 towards prostate cancer cells are enhanced by Zn 2+ -chelation and inhibiting the serine protease Omi/HtrA2. Prostate 2014;75:360-369.

51 Zhang C, Lu X, Tan Y, Li B, Miao X, Jin L, Shi X, Zhang X, Miao L, Li X, Cai L: Diabetes-induced hepatic pathogenic damage, inflammation, oxidative stress, and insulin resistance was exacerbated in zinc deficient mouse model. PLoS One 2012; 7:e49257.

52 Zhaoming Xu, Purtzki M: Zinc Depletion-induced Apoptosis in Human Breast Cancer MDA-MB-231 Cells Is Calcium-dependent. FASEB J 2010;24:S928.

-53 Juriol LV, Gobetto MN, Abregú FMG, Dasso ME, Pineda G, Güttlein L, Carranza A, Podhajcer O, Toblli JE, Elesgaray R: Cardiac changes in apoptosis, inflammation, oxidative stress, and nitric oxide system induced by prenatal and postnatal zinc deficiency in male and female rats. Eur J Nutr DOI:10.1007/s00394-0161343-5. 


\section{Cellular Physiology Cell Physiol Biochem 2017;42:1822-1836 \begin{tabular}{c|l|l}
\hline DOI: 10.1159/000479539 & $\begin{array}{l}\text { () } 2017 \text { The Author(s). Published by S. Karger AG, Basel } \\
\text { www.karger.com/cpb }\end{array}$ \\
and Biochemistry Published online: July 27, 2017 &
\end{tabular}}

Zhu et al.: TPEN Induces Apoptosis in NB4 Cells

54 Matias AC, Manieri TM, Cerchiaro G: Zinc Chelation Mediates the Lysosomal Disruption without Intracellular ROS Generation. Oxid Med Cell Longev DOI: 10.1155/2016/6724585.

55 Zhao YT, Faresin R, Salazar G: Zinc Overload Increases ROS Production and Induces Senescence by a Nox1dependent Mechanism in Vascular Smooth Muscle Cells. FASEB J 2015;29:S761.

-56 Wada S, Matsushita Y, Tazawa H, Aoi W, Naito Y, Higashi A, Ohshima H, Yoshikawa T: Loss of p53 in stromal fibroblasts enhances tumor cell proliferation through nitric-oxide-mediated cyclooxygenase 2 activation. Free Radic Res 2015;49:269-278.

57 Dubey M, Nagarkoti S, Awasthi D, Singh AK, Chandra T, Kumaravelu J, Barthwal MK, Dikshit M: Nitric oxidemediated apoptosis of neutrophils through caspase-8 and caspase-3-dependent mechanism. Cell Death Dis 2016;7:e2348.

-58 Yamaoka J, Kume T, Akaike A, Miyachi Y: Suppressive effect of zinc ion on iNOS expression induced by interferon-gamma or tumor necrosis factor-alpha in murine keratinocytes. J Dermatol Sci 2000;23:27-35.

-59 Cortese-Krott MM, Kulakov L, Opländer C, Kolb-Bachofen V, Kröncke KD, Suschek CV: Zinc regulates iNOSderived nitric oxide formation in endothelial cells. Redox Biol 2014;2:945-954.

60 Wang G, Yan Q, Woods A, Beier F: Rac1/iNos/nitric oxide signaling is required for chondrocyte proliferation and endochondral bone growth. Bone 2008;43:S32.

61 St Croix CM, Wasserloos KJ, Dineley KE, Reynolds IJ, Levitan ES, Pitt BR: Nitric oxide-induced changes in intracellular zinc homeostasis are mediated by metallothionein/thionein. Am J Physiol Lung Cell Mol Physiol 2002;282:L185-192.

62 Pearce LL, Wasserloos K, St Croix CM, Gandley R, Levitan ES, Pitt BR: Metallothionein, nitric oxide and zinc homeostasis in vascular endothelial cells. J Nutr 2000;130:1467S. 